\title{
A Summary of Water Suitability Criteria for Irrigation
}

Abou El-Defan, T. A. ; S. A. A. El-Raies ; H. M. El-Kholy and A. Sh. A. Osman

Soils, Water \& Environment Research Institute, Agric.Res.Center, Giza, Egypt.

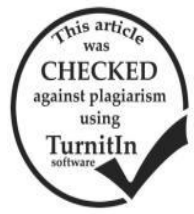

\section{ABSTRACT}

This scientific article aims to summarize the most important measurements of the quality of water for use in irrigation of various crops. The goal is to help professionals and researchers in the soil, water and environment field in the selection of appropriate alternatives to face potential problems that may occur because the use of low quality water in irrigation, which may adversely affect the characteristics of the soil and thus reduce productivity and quality of crops cultivated .The most important measurements, which are summarized in this article includes measurements of salinity risk, measurements the risks of both of soil sodicity and alkalinity, soil permeability for water quality and the specific hazards of some toxic ions .

\section{ITRODUCTION}

Irrigation water usually contains impurities in form of suspended materials, dissolved salts, organic and inorganic pollutants... etc. The amount and nature of these materials under given environmental, climate, soil and plant conditions determine the usefulness and relative quality of water.

Therefore, the use of various type of water for irrigation has made it necessary to create a system of classification. Such classification is usually based on the total salt content and sodium concentration. Aside from these two main criteria, there are some additional factors that are frequently taken into considerations as sodicity, sodium adsorption ratio ....etc. As these hazards do not always appear concurrently, in classifying water for irrigation, it is not necessary to consider them all .So; it is not possible to develop a universal classification suitable for all purposes.

The objective of this scientific essay is summarizing of the most measurements of water quality and comparative between of some common used classifications. Moreover, help the specialists and researchers in the field of soil, water and environment to better understanding the effect of bad quality of water upon soil and crops. As well as, assist them in selecting suitable alternatives to facing with the potential problems related with water quality which that might affect negatively on soil characteristics and then reduce crop yield production.

\section{Irrigation Water Criteia}

\section{- Salinity}

Increasing salts in the soil, as a result of irrigate with saline water, led to decreasing the water uptake by growing plants. If it damage effects continued along the duration of the crop growth without facing, will extend the damage to the crop output quantitatively and qualitatively.

Salts content of the irrigation water is measured

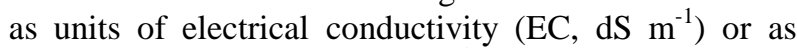
total dissolved Salts (TDS, $\mathrm{mg} \mathrm{l}^{-1}$ "ppm").

According to Richards (1954) salinity of irrigation water was divided into four classes and dented as $\mathrm{C} 1$ to $\mathrm{C} 4$ (Table 1). Limits of salinity of every class and its suitability for soil and growing crops and suitable precautions must be introduced and crop qualities that must be cultivated were remarked in front of every class. Other classifications suggested by UCCC (1974) are shown in Table (2).

Table 1 . Classes of irrigation water salinity.

\begin{tabular}{|c|c|c|c|c|}
\hline \multicolumn{2}{|c|}{ Water class for Salinity } & \multicolumn{2}{|c|}{ Irrigation Water Salinity } & \multirow{2}{*}{ Remarks } \\
\hline Class & Description & $E C,\left(d S m^{-1}\right)$ & $T D S,(p p m)$ & \\
\hline $\mathrm{C} 1$ & Low Salinity & $<0.25$ & $<200$ & $\begin{array}{l}\text { Used for irrigation for most crops on most soils. Some leaching required under normal } \\
\text { irrigation practices, but excess irrigation is required in extremely low permeability soil. }\end{array}$ \\
\hline $\mathrm{C} 2$ & Medium Salinity & $0.25-0.75$ & $200-500$ & $\begin{array}{l}\text { Can be used if a moderate amount of leaching occurs. Plants with moderate salt tolerance } \\
\text { can be grown in most instances without special practices for salinity control. }\end{array}$ \\
\hline $\mathrm{C} 3$ & High Salinity & $0.75-2.25$ & $500-1500$ & $\begin{array}{l}\text { Can't be used on soil with restricted drainage. Even with adequate drainage, special } \\
\text { management for salinity control may be required and plants with good salt tolerance } \\
\text { should be selected. }\end{array}$ \\
\hline $\mathrm{C} 4$ & Very high Salinity & $>2.25$ & $>1500$ & $\begin{array}{l}\text { Not suitable for irrigation under ordinary conditions but may be used occasionally under } \\
\text { very special circumstances . The soils must be permeable, drainage must be adequate, } \\
\text { irrigation water must be applied in excess to provide considerable leaching, and very } \\
\text { salt-tolerant crops should be selected. }\end{array}$ \\
\hline
\end{tabular}

Table 2 . Potential of irrigation problems based on salinity values

\begin{tabular}{lcccc}
\hline \multicolumn{3}{c}{ Potential of } & \multirow{2}{*}{ Units } & \multicolumn{3}{c}{$\begin{array}{c}\text { Degree of problem } \\
\text { Irrigation Problem }\end{array}$} & & None & Slight to Moderate & Severe \\
\hline $\mathrm{EC}_{\mathrm{w}}$ & $\mathrm{dS} / \mathrm{m}$ & $<0.7$ & $0.7-3.0$ & $>3.0$ \\
$\mathrm{TDS}$ & $\mathrm{mg} / 1$ & $<450$ & $450-2000$ & $>2000$ \\
\hline
\end{tabular}

\section{Salt Index}

Researches indicated that the safety limits permitted (accepted safe limit) to salinity in irrigation water is $600 \mathrm{mg} \mathrm{kg}^{-1}$.

When water containing salts in the range of 600 to $1200 \mathrm{mg} \cdot \mathrm{kg}^{-1}$, it is necessary to appreciated saltiness guide (Salt Index). Also, this assessment is used to predict the risk of sodic. It is defined with the relationship between mono-valent sodium ions (Total $\mathrm{Na}^{+}$) and divalent calcium ions in $\mathrm{CaCO}_{3}$ (Total $\mathrm{Ca}^{2+}$ ), which found in irrigation and the estimated, as ppm i.e., $\mathrm{mg} . \mathrm{l}^{-1}$ and can be calculated by using the following formula for Singh (2005):

Salt index $=\left[\left(\right.\right.$ Total $\left.^{+}{ }^{+}-24.5\right)-\left(\right.$ total $\mathrm{Ca}^{2+}$ in $\left.\left.\mathrm{CaCO}_{3}\right)\right] \times 4.85$

Water quality for irrigation according to the obtained value could be evaluated as:

-Negative value, mean good water quality for use in irrigation. 
-Positive value, mean water quality is not suitable for use for irrigation.

- Upper limit of the total salts which beyond it; water becomes unsuitable for irrigation is $1200 \mathrm{mg} \mathrm{kg} \mathrm{l}^{-1}$.

\section{(II) Sodicity}

Sodium is not necessary element for plant growth, in spite of uptake a large amount by some of the plants, although of toxic effects of the majority of plants. Intensity effects of sodium cation in the quality of irrigation water, depends on the anion accompanying as chloride, sulphate, carbonate, bicarbonate anion. But, sodium ion is the most important soluble ions in soilwater system, and the main cause on occurrences sodicity in the soil, because the adsorption of sodium cations on soil particles. The most important measures of sodium hazards in the past and recently, will be summarizing as follow.

\section{1) Sodium ratio $(\mathrm{SR})$}

In the past, the quality of irrigation water was evaluated as a ratio between the dissolved cations of sodium and the total calcium \& magnesium in irrigation water, which dented as (SR) and calculated by the equation of:

$\mathrm{SR}=\left(\mathrm{Na}^{+}\right) /\left(\mathrm{Ca}^{2+}+\mathrm{Mg}^{2+}\right)$ all the ions concentrations expressed as meq. $l^{-1}$.

In good water this ratio should not be worth more than (1).

\section{2) Soluble Sodium Percentage (SSP)}

Sodium is the more soluble and dangerous ion in irrigation water. Excess sodium ions in irrigation water are the characters of sodic water, and in case of increasing in the soil, change soil to sodic characteristics. Also, in past the measure of irrigation water quality was assessed on the basis of percent of soluble sodium concentration (meq. $l^{-1}$ ) as the total concentrations of cations (meq. $l^{-1}$ ), which expressed as (SSP) as follows:
This measurement is helpful in describing the qualities of the water, because with soluble sodium percentage equal to or more than $66 \%$ (SSP $\geq 66$ ), the use of this water lead to a part of sodium ions adsorbed on the soil particles and their properties become bad as well as the growing plants adversely affected. Bad properties of the sodic soil represented in low of soil permeability for water $\&$ air and the soil become very solid when dry and sticky when wet. These bad characters of soil, in generally, lead the soil to become difficult to perform agricultural operations, whereas it breakdown the aggregates (deflocculation) to fine particles, which moving down the soil and deposited between pores causing close it (sealing the pores). Consequently, its permeability of water more decreased.

\section{3) Sodium Adsorption Ratio (SAR)}

Several ways were carried out, in past, to predict the expected risks from the excess sodium of irrigation water in reducing the permeability of water through the soil. Residual Sodium Carbonate (RSC) was the most prevalent evaluation in the past. Subsequently USSL (1954) introduced the concept of Sodium Adsorption Ratio (SAR) to assess the potential risks of sodic of irrigation water on the soil permeability, then become the most common evaluation till now.

The sodium hazards of irrigation water expressed through SAR does not take into account the effects of anionic composition, but it is used to expect the sodium cation which adsorbed on soil particles from sodium prevailing in irrigation water.

It is calculated by the following formula, whereas all the ions expressed as meq. $l^{-1}$

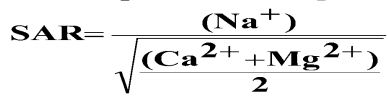

On the other hand, (Richards, 1954) classified irrigation water to four types according to the hazard effects of SAR, which shown in Table (3).

Table 3. Irrigation water classes and description as SAR values (Water Sodicity).

\begin{tabular}{lccc}
\hline $\begin{array}{l}\text { Water class \& Description } \\
\text { Class }\end{array}$ & Description & SAR & Remarks \\
S1 & $\begin{array}{c}\text { low sodium } \\
\text { Water }\end{array}$ & $<10$ & $\begin{array}{c}\text { Can be used for irrigation on almost all of soil with little danger of the development exchangeable } \\
\text { sodium. However sodium sensitive crops may accumulate injurious concentration of sodium. }\end{array}$ \\
\hline S2 & $\begin{array}{c}\text { medium sodium } \\
\text { Water }\end{array}$ & $10-18$ & $\begin{array}{c}\text { Appreciable sodium hazard in fine-textured soil having CEC especially under low leaching conditions, } \\
\text { unless gypsum is present in the soil. But can be used on coarse textured or organic soil with good } \\
\text { permeability. }\end{array}$ \\
\hline S3 & $\begin{array}{c}\text { High sodium } \\
\text { Water }\end{array}$ & $18-26 \begin{array}{c}\text { Unsatisfactory for most of the crops and may produce harmful levels of exchangeable sodium. Most } \\
\text { of soil will require special soil management i.e. good drainage, high leaching and organic matter } \\
\text { additions. Gypsi-ferous soils may not develop harmful levels of exchangeable sodium from such } \\
\text { water. Chemical amendments may be required for replacement exchangeable sodium. }\end{array}$ \\
\hline S4 & $\begin{array}{c}\text { Very high sodium } \\
\text { Water }\end{array}$ & $>26$ & $\begin{array}{c}\text { Is general unsatisfactory for irrigation purposes, most of the crops, except at low and perhaps medium } \\
\text { salinity, where the solution of calcium from the soil or use of gypsum may make the use of these water } \\
\text { feasible. }\end{array}$ \\
\hline
\end{tabular}

Evaluation water for irrigation according to the hazards effects for both of (ECw, $\mu \mathrm{mho} / \mathrm{cm}$ at $\left.25 \mathrm{C}^{\circ}\right)$ and (SAR):

Moreover, the staff of USSL (1954) used a special diagram of Wilcox (1948), for evaluating the water for irrigation purposes according to the hazards effects for both of $\left(\mathrm{ECw}, \mu \mathrm{mho} / \mathrm{cm}\right.$ at $\left.25 \mathrm{C}^{\circ}\right)$ and sodicity (SAR).

According to this diagram scheme, the four classes of ECw, ( $\mu \mathrm{mho} / \mathrm{cm}$ at $\left.25 \mathrm{C}^{\circ}\right)$ in Table (1) were plotted on " $\mathrm{X}$ " axis and the four classes of (SAR) in Table (3) were plotted on "Y" axis as shown in Fig. (1).
Richards (1954) produced some notes must be considered when the use of water for irrigation:

- Irrigation water may sometimes dissolve sufficient calcium from calcareous soils to decrease the sodium hazard appreciably, and this should be taken into account in the use of $\mathrm{Cl}-\mathrm{S3}$ and $\mathrm{Cl}-\mathrm{S} 4$ waters.

- For calcareous soils with high pH values or for noncalcareous soils, the sodium status of waters in classes $C 1-S 3, C 1-S 4$ and C2-S4 may be improved by the addition of gypsum to the water. 
- $\quad$ Similarly, it may be beneficial to add gypsum to the soil periodically when $C 2-S 3$ and $C 3-S 2$ waters are used.

\section{4) Adjusted Sodium Adsorption Ratio (adj SAR)}

Late, Ayers and Wescot (1976) pointed out that, sodicity hazard of irrigation water should be determined by Adjusted SAR (adj.SAR) to predict sodicity hazards more correctly for those water which contain appreciable amounts of $\mathrm{HCO}_{3}{ }^{-}$but no RSC, which be calculated as follows :

adj. SAR = SAR $\{1+(8.4-$ pHc $)\}$

Where: SAR = Sodium Adsorption Ratio

$\mathbf{p H}_{\mathrm{C}}=\left(\mathbf{p K} \mathrm{K}_{2}-\mathbf{p K c}\right)+\mathbf{p}(\mathrm{Ca}+\mathrm{Mg})+\mathbf{p}(\mathrm{Alk})$

The components of (pHC) formula will be obtained as follow:

$\left(\mathbf{p K}_{\mathbf{2}}-\mathbf{p K c}\right)$ These formulas will be replaced by the $\mathrm{Ca}+\mathrm{Mg}+\mathrm{Na}\left(\right.$ meq. $\left.l^{-1}\right)$

$\mathbf{p}(\mathbf{C a}+\mathbf{M g})$ values corresponding to total ions $\mathrm{Ca}+\mathrm{Mg}$ (meq. $\left.l^{-1}\right)$

- $\mathbf{p}(\mathbf{p A l k})$ concentration values in front of every $\mathrm{CO}_{3}+\mathrm{HCO}_{3}\left(\right.$ meq. $l^{-1}$ ) formula from Table (4).

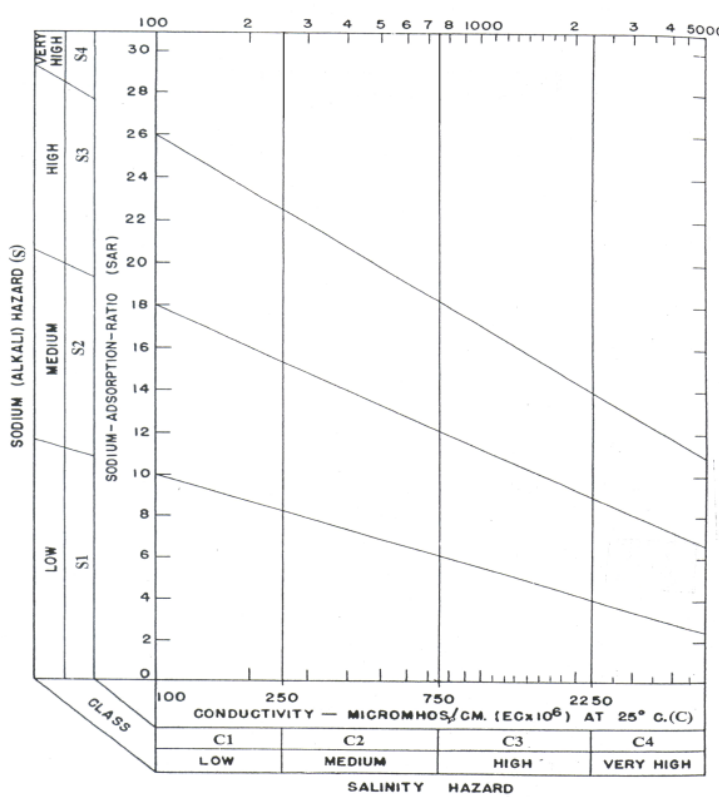

Fig 1. Classification of irrigation water according to the degree of risks for both of $(\mathrm{ECw})$ and (SAR), Wilcox (1948)

Example of the method for calculating the $\left(\mathrm{pH}_{\mathrm{c}}\right)$ and (adj.SAR) :

Given: The water analysis is: $\mathrm{EC}_{\mathrm{w}}=1.15 \mathrm{dS} / \mathrm{m}$

$\mathrm{Ca}^{+2}=2.32$ meq. $/ 1, \mathrm{Mg}^{+2}=1.44$ meq. $/ 1, \mathrm{Na}^{+}=7.73 \mathrm{me} / \mathrm{l}^{-1}$

$\mathrm{CO}_{3}{ }^{-2}=0$. Meq./1 , $\mathrm{HCO}_{3}{ }^{-}=3.66$ meq./1

Explanation Solution:

(1) $\mathrm{Ca}+\mathrm{Mg}+\mathrm{Na}=11.49 \mathrm{meq} / \mathrm{l}, \mathrm{Ca}+\mathrm{Mg}=3.76$ meq./1 $\mathrm{CO}_{3}+\mathrm{HCO}_{3}=4.08$ meq./1

$$
S A R=\frac{7.73}{\sqrt{\frac{2.32+1.44}{2}}}=5.64
$$

(3) $\left(\mathrm{pK}_{2}-\mathrm{pK}_{\mathrm{c}}\right)=2.3[(2.3)$ is the value correspond to" $\mathrm{Ca}+\mathrm{Mg}+\mathrm{Na}$ - 11.5"column 2"]

$\mathrm{P}(\mathrm{Ca}+\mathrm{Mg})=2.7[(2.7)$ is the value correspond to "Ca+ Mg 23.8 "column 3"]
$\mathrm{P}(\mathrm{Alk})=2.4 \quad[(2.3)$ is the value correspond to " $\mathrm{CO}_{3+} \mathrm{HCO}_{3} \simeq 4$ " in "column 4"]

Then, $\mathrm{pHc}=(2.3+2.7+2.4)=7.4$

(4) Since: adj. SAR $=$ SAR $\{1+(8.4-\mathrm{pHc})\}$

Then: $(\operatorname{adj}$ SAR $=5.64[1+(8.4-7.4))]=11.3$

Table 4. Procedure for calculation of $\mathrm{pHc}$

\begin{tabular}{|c|c|c|c|}
\hline \multirow{4}{*}{$\begin{array}{l}\text { Concentration }(m e / l) \text { of } \\
(\mathrm{Ca}+\mathrm{Mg}+\mathrm{Na}) \text { or } \\
(\mathrm{Ca}+\mathrm{Mg}) \text { or } \\
\left(\mathrm{CO}_{3}+\mathrm{HCO}_{3}\right)\end{array}$} & \multicolumn{3}{|c|}{ Values of $\mathrm{pH}_{\mathrm{C}}$ Components } \\
\hline & $\mathrm{pK}_{2}-\mathrm{pKc}$ & $\mathbf{P}(\mathrm{Ca}+\mathrm{Mg})$ & p(Alk) \\
\hline & \multicolumn{3}{|c|}{ Versus the sum of } \\
\hline & $\overline{(\mathrm{Ca}+\mathrm{Mg}+\mathrm{Na})}$ & $(\mathrm{Ca}+\mathrm{Mg})$ & $\left(\mathrm{CO}_{3}+\mathrm{HCO}_{3}\right)$ \\
\hline 0.05 & 2.0 & 4.6 & 4.3 \\
\hline 0.10 & 2.0 & 4.3 & 4.0 \\
\hline 0.15 & 2.0 & 4.1 & 3.8 \\
\hline 0.20 & 2.0 & 4.0 & 3.7 \\
\hline 0.25 & 2.0 & 3.9 & 3.6 \\
\hline 0.30 & 2.0 & 3.8 & 3.5 \\
\hline 0.40 & 2.0 & 3.7 & 3.4 \\
\hline 0.50 & 2.1 & 3.6 & 3.3 \\
\hline 0.75 & 2.1 & 3.4 & 3.1 \\
\hline 1.00 & 2.1 & 3.3 & 3.0 \\
\hline 1.25 & 2.1 & 3.2 & 2.9 \\
\hline 1.50 & 2.1 & 3.1 & 2.8 \\
\hline 2.00 & 2.2 & 3.0 & 2.7 \\
\hline 2.50 & 2.2 & 2.9 & 2.6 \\
\hline 3.00 & 2.2 & 2.8 & 2.5 \\
\hline 4.00 & 2.2 & 2.7 & 2.4 \\
\hline 5.00 & 2.2 & 2.6 & 2.3 \\
\hline 6.00 & 2.2 & 2.5 & 2.2 \\
\hline 8.00 & 2.3 & 2.4 & 2.1 \\
\hline 10.00 & 2.3 & 2.3 & 2.0 \\
\hline 12.50 & 2.3 & 2.2 & 1.9 \\
\hline 15.00 & 2.3 & 2.1 & 1.8 \\
\hline 20.00 & 2.4 & 2.0 & 1.7 \\
\hline 30.00 & 2.4 & 1.8 & 1.5 \\
\hline 50.00 & 2.5 & 1.6 & 1.3 \\
\hline 80.00 & 2.5 & 1.4 & 1.1 \\
\hline
\end{tabular}

$\mathrm{pHc}$, is a theoretical calculated $\mathrm{pH}$ of the irrigation water.

Important notes:

- In the same connection ,Wilcox (1966) interpreted of the $\mathrm{pH}_{\mathrm{c}}$ values, and explained that:

- $\mathrm{pH}_{\mathrm{c}}$ values higher than 8.4 indicate a tendency to dissolve lime from the soil through which the water moves.

- $\mathrm{pH}_{\mathrm{c}}$ values less than 8.4 indicate a tendency to precipitate lime from the water applied.

- Increase the values of $\mathrm{pH}_{\mathrm{c}}$ than 8.4 mean that decrease of the (adj.SAR) values and vice versa.

- Also, the tendency of water to cause calcium precipitation can be predicted by using saturation index, which is defined as the actual $\mathrm{pH}$ of the water ( $\mathrm{pHa})$ minus the theoretical $\mathrm{pH}(\mathrm{pHc})$ of the same water, that the water could have it, if in equilibrium with $\mathrm{CaCO}_{3}$.

While: Saturation Index $=\mathrm{pHa}-\mathrm{pHc}$, whereas:

* (pHa) values can be obtained from laboratory data.

$*(\mathrm{pHc})$ is estimated as described above and by using Table (4). The values of saturation index denoted that:

**Positive values of saturation index mean that ( $\mathrm{pHa}$ $>\mathrm{pHc}$ ) and indicate a tendency for $\mathrm{CaCO}_{3}$ to precipitate from the water.

** Negative values of of saturation index mean that $(\mathrm{pHa}<$ $\mathrm{pHc}$ ) and indicate that the water will dissolve $\mathrm{CaCO}_{3}$.

- It must be estimated the "adi.SAR" value for the quality of irrigation water that have EC values 
$1.5<\mathrm{EC}<3.0$ (greater than 1.5 and less than 3.0, $\mathrm{dS} / \mathrm{m}$ ) because this quality have the highest expectation in causes more double sodic hazards raised from both of the RSC and the SAR.

Ayers and Westcot (1976) introduced guidelines of the adi.SAR problems and the degree of hazards of them on the soil permeability and their relevance with both of clay mineral type and irrigation water salinity $\left(\mathrm{EC}_{\mathrm{W}}, \mathrm{dS} / \mathrm{m}\right)$ as shown in Table (5).

- Ayers and Westcot (1976) reported that, (adjusted SAR) is no longer recommended. However, Oster and Rhoades (1977), Oster and Schroer (1979) and Suarez (1981) carefully evaluated this procedure and concluded that it over predicts the sodium hazard. They suggest that, if used the value obtained by that method should be further adjusted by a 0.5 factor to evaluate more correctly the effects of $\mathrm{HCO}_{3}$ on calcium precipitation (adj SAR $\times 0.5$ )

Table 5. Guidelines of (adj. SAR) problems on infiltration rate of water into the soil.

\begin{tabular}{|c|c|c|c|}
\hline \multirow{3}{*}{$\begin{array}{l}\text { Clay mineral Type } \\
\text { Monomorillonite (2:1 crystal lattice) }\end{array}$} & \multirow{2}{*}{\multicolumn{3}{|c|}{$\begin{array}{l}\text { Degree of hazards } \\
\text { No Increasing Severe } \\
\text { adj. SAR values }\end{array}$}} \\
\hline & & & \\
\hline & $<6$ & $6-9$ & $>9$ \\
\hline & $<8$ & 8 & \\
\hline$(1: 1$ crystal lattice) & $<16$ & $16-24$ & $>24$ \\
\hline $\begin{array}{l}\text { Suitable } \mathrm{EC}_{\mathrm{w}}(\mathrm{dS} / \mathrm{m}) \text { for use for the } \\
\text { tabulated ranges }\end{array}$ & $<0.4$ & $0.4-1.6$ & $>1.6$ \\
\hline
\end{tabular}

\section{5) Adjusted Sodium Adsorption Ratio for Calcium $\left(\operatorname{adj} \mathbf{R}_{\mathrm{Na}}\right)$}

Assessment SAR expresses the resulting problems due to an excess of sodium and does not take into account the solubility or deposition of calcium ions in soil-water system before or after the irrigation. So, SAR equation does not take into account these changes, thus some errors may be occurrence. However, the use of SAR equation still considered an acceptable assessment for most of the water used for irrigation water samples to express on the sodicity hazards.

Recently, the newer (adj $\mathrm{R}_{\mathrm{Na}}$ ) procedure of Suarez (1981) is recommended, but both the older SAR procedure and the new (adj $\mathrm{R}_{\mathrm{Na}}$ ) are acceptable, with a preference expressed towards the $\left(\operatorname{adj} R_{N a}\right.$ because it and the $\mathrm{Ca}_{\mathrm{x}}$ of Table (6) offer a better insight into the change in calcium in the soil-water due to addition by dissolution of calcium from soil carbonates, or loss of calcium from soil-water by precipitation as carbonates. This is due to part of calcium in the saline water precipitate by partial pressure of air carbon dioxide when saline water adjacent to the soil. So, it is need to correct calcium in the saline water as in Table (6) between the ratio of $\mathrm{HCO}_{3}{ }^{=} / \mathrm{Ca}^{2+}$ and $\mathrm{EC}_{\mathrm{w}}$.

Thus $\left(\operatorname{adj} R_{\mathrm{Na}}\right)$ is considered an alternative procedure, takes a new look at the older SAR equation. Furthermore, $\left(\operatorname{adj} R_{\mathrm{Na}}\right)$ adjusts the calcium concentration of the irrigation water to the expected equilibrium value following an irrigation, and includes the effects of carbon dioxide $\left(\mathrm{CO}_{2}\right)$, of bicarbonate $\left(\mathrm{HCO}_{3}\right)$ and of salinity $(\mathrm{ECW})$ upon the calcium originally present in the applied water but now a part of the soil-water. Also, this procedure assumes a soil source of calcium from soil lime $\left(\mathrm{CaCO}_{3}\right)$ and no precipitation of magnesium.

Table 6. Calcium concentration $\left(\mathrm{Ca}_{\mathrm{x}}\right)$ expected to remain in near-surface soil-water following irrigation with water of given $\mathrm{HCO}_{3} / \mathrm{Ca}$ ratio and $\mathrm{EC}_{\mathrm{w}}{ }^{1,2,3}$.

\begin{tabular}{|c|c|c|c|c|c|c|c|c|c|c|c|c|c|}
\hline & & \multicolumn{12}{|c|}{ Salinity of applied water (ECw , dS/m) } \\
\hline & & 0.1 & 0.2 & 0.3 & 0.5 & 0.7 & 1.0 & 1.5 & 2.0 & 3.0 & 4.0 & 6.0 & 8.0 \\
\hline & & \multicolumn{12}{|c|}{ Cax values } \\
\hline & 0.05 & 13.20 & 13.61 & 13.92 & 14.40 & 14.79 & 15.26 & 15.91 & 16.43 & 17.28 & 17.97 & 19.07 & 19.94 \\
\hline & 0.10 & 8.31 & 8.57 & 8.77 & 9.07 & 9.31 & 9.62 & 10.02 & 10.35 & 10.89 & 11.32 & 12.01 & 12.56 \\
\hline & 0.15 & 6.34 & 6.54 & 6.69 & 6.92 & 7.11 & 7.34 & 7.65 & 7.90 & 8.31 & 8.64 & 9.17 & 9.58 \\
\hline & 0.20 & 5.24 & 5.40 & 5.52 & 5.71 & 5.87 & 6.06 & 6.31 & 6.52 & 6.86 & 7.13 & 7.57 & 7.91 \\
\hline & 0.25 & 4.51 & 4.65 & 4.76 & 4.92 & 5.06 & 5.22 & 5.44 & 5.62 & 5.91 & 6.15 & 6.52 & 6.82 \\
\hline & 0.30 & 4.00 & 4.12 & 4.21 & 4.36 & 4.48 & 4.62 & 4.82 & 4.98 & 5.24 & 5.44 & 5.77 & 6.04 \\
\hline & 0.35 & 3.61 & 3.72 & 3.80 & 3.94 & 4.04 & 4.17 & 4.35 & 4.49 & 4.72 & 4.91 & 5.21 & 5.45 \\
\hline & 0.40 & 3.30 & 3.40 & 3.48 & 3.60 & 3.70 & 3.82 & 3.98 & 4.11 & 4.32 & 4.49 & 4.77 & 4.98 \\
\hline & 0.45 & 3.05 & 3.14 & 3.22 & 3.33 & 3.42 & 3.53 & 3.68 & 3.80 & 4.00 & 4.15 & 4.41 & 4.61 \\
\hline & 0.50 & 2.84 & 2.93 & 3.00 & 3.10 & 3.19 & 3.29 & 3.43 & 3.54 & 3.72 & 3.87 & 4.11 & 4.30 \\
\hline & 0.75 & 2.17 & 2.24 & 2.29 & 2.37 & 2.43 & 2.51 & 2.62 & 2.70 & 2.84 & 2.95 & 3.14 & 3.28 \\
\hline & 1.00 & 1.79 & 1.85 & 1.89 & 1.96 & 2.01 & 2.09 & 2.16 & 2.23 & 2.35 & 2.44 & 2.59 & 2.71 \\
\hline Ratio of & 1.25 & 1.54 & 1.59 & 1.63 & 1.68 & 1.73 & 1.78 & 1.86 & 1.92 & 2.02 & 2.10 & 2.23 & 2.33 \\
\hline (HCO3 / & 1.50 & 1.37 & 1.41 & 1.44 & 1.49 & 1.53 & 1.58 & 1.65 & 1.70 & 1.79 & 1.86 & 1.97 & 2.07 \\
\hline $\mathrm{Ca}$ ) & 1.75 & 1.23 & 1.27 & 1.30 & 1.35 & 1.38 & 1.43 & 1.49 & 1.54 & 1.62 & 1.68 & 1.78 & 1.86 \\
\hline & 2.00 & 1.13 & 1.16 & 1.19 & 1.23 & 1.26 & 1.31 & 1.36 & 1.40 & 1.48 & 1.54 & 1.63 & 1.70 \\
\hline & 2.25 & 1.04 & 1.08 & 1.10 & 1.14 & 1.17 & 1.21 & 1.26 & 1.30 & 1.37 & 1.42 & 1.51 & 1.58 \\
\hline & 2.50 & 0.97 & 1.00 & 1.02 & 1.06 & 1.09 & 1.12 & 1.17 & 1.21 & 1.27 & 1.32 & 1.40 & 1.47 \\
\hline & 3.00 & 0.85 & 0.89 & 0.91 & 0.94 & 0.96 & 1.00 & 1.04 & 1.07 & 1.13 & 1.17 & 1.24 & 1.30 \\
\hline & 3.50 & 0.78 & 0.80 & 0.82 & 0.85 & 0.87 & 0.90 & 0.94 & 0.97 & 1.02 & 1.06 & 1.12 & 1.17 \\
\hline & 4.00 & 0.71 & 0.73 & 0.75 & 0.78 & 0.80 & 0.82 & 0.86 & 0.88 & 0.93 & 0.97 & 1.03 & 1.07 \\
\hline & 4.50 & 0.66 & 0.68 & 0.69 & 0.72 & 0.74 & 0.76 & 0.79 & 0.82 & 0.86 & 0.90 & 0.95 & 0.99 \\
\hline & 5.00 & 0.61 & 0.63 & 0.65 & 0.67 & 0.69 & 0.71 & 0.74 & 0.76 & 0.80 & 0.83 & 0.88 & 0.93 \\
\hline & 7.00 & 0.49 & 0.50 & 0.52 & 0.53 & 0.55 & 0.57 & 0.59 & 0.61 & 0.64 & 0.67 & 0.71 & 0.74 \\
\hline & 10.00 & 0.39 & 0.40 & 0.41 & 0.42 & 0.43 & 0.45 & 0.47 & 0.48 & 0.51 & 0.53 & 0.56 & 0.58 \\
\hline & 20.00 & 0.24 & 0.25 & 0.26 & 0.26 & 0.27 & 0.28 & 0.29 & 0.30 & 0.32 & 0.33 & 0.35 & 0.37 \\
\hline & 30.00 & 0.18 & 0.19 & 0.20 & 0.20 & 0.21 & 0.21 & 0.22 & 0.23 & 0.24 & 0.25 & 0.27 & 0.28 \\
\hline
\end{tabular}

1) Adapted from Suarez (1981).

2) Assumes a soil source of calcium from lime $\left(\mathrm{CaCO}_{3}\right)$ or silicates; no precipitation of magnesium, and partial pressure of $\mathrm{CO}_{2}$ near the soil surface $\left(\mathbf{P}_{\mathrm{CO} 2}\right)$ is $\mathbf{. 0 0 0 7}$ atmospheres.

3) $\mathrm{Ca}_{\mathrm{x}}, \mathrm{HCO}_{3}, \mathrm{Ca}$ are reported in meq. $\mathrm{I}^{-1}, \mathrm{EC}_{\mathrm{w}}$ is in $\mathrm{dS} / \mathrm{m}$. 
The new term for this is Adjusted Sodium Ratio for Calcium, i.e. "adj $\mathrm{R}_{\mathrm{Na}}$ " and the calculation procedure is presented in the following example as an improvement on the older "SAR" (Sodium Adsorption Ratio). It can be used to predict more correctly potential infiltration problems due to relatively high sodium (or low calcium) in irrigation water supplies (Suarez 1981) and (Rhoades 1982). The equation for calculation of adj $\mathrm{R}_{\mathrm{Na}}$ is very similar to the older SAR and give values very close to the values of SAR (Table 7). The formula for calculation of adj $R_{\mathrm{Na}}$ is:

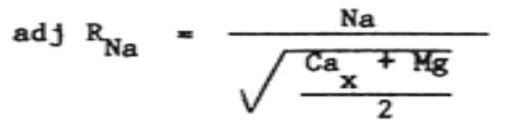

\section{Where:}

$\mathrm{Na}$ : sodium in the irrigation water as meq. $l^{-1}$

$\mathrm{Ca}_{\mathrm{x}}$ : A modified calcium value, in meq. $l^{-1}$, taken from Table (6).

$\mathrm{Ca}_{\mathrm{x}}$ represents $\mathrm{Ca}$ in the applied irrigation water but modified due to ratio of $\mathrm{HCO}_{3} / \mathrm{Ca}$ ratio $\left(\mathrm{HCO}_{3}\right.$ and $\mathrm{Ca}$ in me/l) and the estimated partial pressure of $\mathrm{CO}_{2}$ in the surface few millimeters of soil $\left(\mathrm{PCO}_{2}=\right.$ 0.0007 atmospheres).
Mg: Magnesium in the irrigation water reported meq.l ${ }^{l}$ Example of the method for calculating the $\left(\operatorname{adj} . \mathbf{R}_{\mathrm{Na}}\right)$ : Given:

$\mathrm{ECw}=2.74 \mathrm{dS} / \mathrm{m}$,

$\mathrm{Ca}=7.73$ meq..$^{-1}$

$\mathrm{Mg}=9.06$ meq..$^{-1}$,

$\mathrm{Na}=12.07$ meq..$^{-1}$,

$\mathrm{HCO}_{3}=1.56$ meq. $1^{-1}$.

Explanation Solution:

Since: $\left(\mathrm{HCO}_{3} / \mathrm{Ca}\right)=1.56 / 7.73$ meq. $1^{-1}$,

$\mathrm{ECw} \simeq 3.0 \mathrm{dS} / \mathrm{m}$.

Then: $\mathrm{HCO}_{3} / \mathrm{Ca}=0.20$ and then from Table (6):

$\mathrm{Ca}_{\mathrm{x}}=6.86$ meq. $1^{-1}$.

$$
\operatorname{adjR}_{N a}=\frac{12.07}{\sqrt{\frac{6.86+9.06}{2}}}=4.28
$$

\section{Then:}

Table (7) shows the chemical analysis of the number 21 sample irrigation water and compare between their calculated values for each of the (SAR), $\left(\operatorname{adj} \mathrm{R}_{\mathrm{Na}}\right.$ ) and $(\operatorname{adj} \mathrm{SAR})$. This table showed a clear rapprochement between the values of both of (SAR) and the (adi $\mathrm{R}_{\mathrm{Na}}$ ), as previously clarify that .

Table 7. Comparison the calculated data of SAR, Adj RNa and Adj SAR.

\begin{tabular}{|c|c|c|c|c|c|c|c|c|c|c|c|c|}
\hline \multirow{2}{*}{$\begin{array}{l}\text { Samples } \\
\text { No }\end{array}$} & \multicolumn{6}{|c|}{ Chemical composition of irrigation water samples } & \multicolumn{6}{|c|}{ Assessment of sodicity hazards } \\
\hline & $\begin{array}{c}\text { EC } \\
(\mathrm{dS} / \mathrm{m})\end{array}$ & $\mathrm{Ca}^{2+}$ & $\begin{array}{c}\text { Ion conc } \\
\mathrm{Mg}^{2+}\end{array}$ & $\begin{array}{c}\text { entratio } \\
\mathrm{Na}^{+}\end{array}$ & $\mathrm{CO}_{3}^{-}$ & $\mathrm{HCO}_{3}^{-}$ & SAR & $\mathrm{HCO}_{3} / \mathrm{Ca}$ & $\mathbf{C a} \mathbf{a}_{\mathbf{x}}$ & adj RNa & pHc & adj SAR \\
\hline 1 & 3.25 & 4.82 & 13.98 & 13.7 & 0 & 1.57 & 4.47 & 0.36 & 4.72 & 4.48 & 7.2 & 9.83 \\
\hline 2 & 2.74 & 7.73 & 9.06 & 12.07 & 0 & 1.56 & 4.17 & 0.20 & 6.86 & 4.28 & 7.3 & 8.75 \\
\hline 3 & 2.74 & 4.99 & 6.75 & 12.13 & 0 & 1.21 & 5.01 & 0.24 & 5.91 & 4.82 & 7.5 & 9.51 \\
\hline 4 & 1.827 & 6.85 & 2.5 & 9.12 & 0 & 2.22 & 4.22 & 0.32 & 4.98 & 4.72 & 7.4 & 8.44 \\
\hline 5 & 1.791 & 5.48 & 2.98 & 8.2 & 0 & 2.13 & 3.97 & 0.39 & 4.11 & 4.36 & 7.4 & 7.97 \\
\hline 6 & 1.808 & 8.1 & 3.28 & 8.26 & 0 & 2.18 & 3.46 & 0.27 & 4.98 & 3.92 & 7.3 & 7.27 \\
\hline 7 & 1.75 & 4.67 & 4.11 & 7.82 & 0 & 2.16 & 3.73 & 0.46 & 3.68 & 3.93 & 7.4 & 7.46 \\
\hline 8 & 4.18 & 6.99 & 6.99 & 27.02 & 0 & 2.38 & 10.22 & 0.34 & 4.91 & 10.54 & 7.35 & 20.95 \\
\hline 9 & 0.861 & 2.45 & 2.68 & 1.96 & 0 & 1.97 & 1.22 & 0.80 & 2.51 & 1.22 & 7.55 & 2.26 \\
\hline 10 & 2.36 & 8.93 & 3.7 & 10.36 & 0.1 & 1.27 & 4.12 & 0.14 & 7.90 & 4.3 & 7.4 & 8.25 \\
\hline 11 & 2.35 & 6.74 & 5.81 & 10.34 & 0.1 & 1.64 & 4.13 & 0.24 & 5.62 & 4.33 & 7.4 & 8.26 \\
\hline 12 & 2.41 & 5.89 & 7.81 & 10.53 & 0 & 1.88 & 4.02 & 0.32 & 4.98 & 4.16 & 7.3 & 8.45 \\
\hline 13 & 2.42 & 9.73 & 2.52 & 10.09 & 0 & 1.23 & 4.08 & 0.13 & 7.90 & 4.42 & 7.5 & 7.75 \\
\hline 14 & 2.14 & 5.51 & 5.76 & 10.22 & 0 & 1.12 & 4.31 & 0.20 & 6.52 & 4.12 & 7.55 & 7.96 \\
\hline 15 & 2.02 & 6.24 & 5.32 & 8.94 & 0 & 1.82 & 3.72 & 0.29 & 4.98 & 3.94 & 7.35 & 7.62 \\
\hline 16 & 2.06 & 6.75 & 4.34 & 9.05 & 0 & 1.79 & 3.84 & 0.27 & 4.98 & 4.06 & 7.4 & 7.69 \\
\hline 17 & 2.05 & 6.81 & 5.43 & 8.98 & 0.1 & 1.99 & 3.63 & 0.29 & 4.98 & 3.94 & 7.3 & 7.62 \\
\hline 18 & 3.27 & 9.75 & 11.51 & 10.97 & 0 & 2.01 & 3.36 & 0.21 & 6.86 & 3.62 & 7.1 & 7.74 \\
\hline 19 & 8.64 & 7.29 & 9.13 & 9.78 & 0 & 2.35 & 3.41 & 0.32 & 6.04 & 3.55 & 7.1 & 7.85 \\
\hline 20 & 2.6 & 8.48 & 6.74 & 9.7 & 0.1 & 1.97 & 3.52 & 0.23 & 5.91 & 3.86 & 7.2 & 7.74 \\
\hline 21 & 6.15 & 26.2 & 20.56 & 12.96 & 0 & 1.53 & 2.68 & 0.06 & 19.07 & 2.91 & 6.9 & 6.7 \\
\hline
\end{tabular}

\section{6) Sodium to calcium activity ratio (SCAR)}

For the group of water quality which has (EC > $\left.5 \mathrm{dS} \mathrm{m}^{-1}\right)$ and $(\mathrm{Mg} / \mathrm{Ca}$ ratio > 1), the estimation accuracy of the SAR is obviously questionable. Gupta and Abichandani (1970) explained that if the SAR of irrigation water equal or more than 8 and the ratio of $(\mathrm{Mg} / \mathrm{Ca})$ greater than 5.4, then the value of ESP, which calculated mathematically from the equation of ESP; dependent on SAR value as described by (Richards, 1954), do not agree with the value of the ESP estimated from laboratory analyzes. Whereas if, SAR calculated from of the relationship: the computational values of ESP show fully consistent with the ESP value estimated by laboratory analyzes. Therefore, (Richards, 1954) defined this relationship as Sodium : Calcium Activity Ratio (SCAR), whereas:

$(\mathrm{SCAR}=$

Because of sodium cation is the more ion of water in the events of the damage on soil if used for irrigation, the best types of irrigation water is a sodium ion does not prevail on the rest of the ions.

When equally the ESP and the SAR values i.e., $\mathrm{ECw}$ is less than $5 \mathrm{dSm}^{-1}$ and ratio of $(\mathrm{Mg} / \mathrm{Ca})$ less $1(<1)$ the water can be used irrigation for without any restriction because it does not have adverse effects on the natural properties of soils and the highest growing plants.

But if the ECw is located between (5-10 dSm-1) and the $(\mathrm{Mg} / \mathrm{Ca})$ is higher than $(2-4)$, then SCAR is concerned 
with a good evaluation of this water when used for irrigation, particularly with regard to the quality suitable crops planted in the soil of this the quality of our water. Therefore, Gupta and Abichandani (1970) ranked irrigation water according to the ratio between (SAR / SCAR) to six categories of:

- Non-sodic waters (S0), (SAR/SCAR < 5): can be used for irrigation on almost all soils, for all crops even those sensitive to sodium such as stone-fruit or wood trees.

- $\quad$ Normal sodicity waters (S1), (SAR/SCAR 5-10): can be used for irrigation on almost all soils with little danger of development of harmful levels of exchangeable sodium for growing all crops except some stone-fruit trees or wood trees which are specially sensitive to sodium. These waters do not have any requirement for leaching and/or amendments.

- Low sodicity waters (S2), (SAR/SCAR 10-20): can be used for crops which are semi-tolerant or tolerant to sodium on almost all soils so that $\mathrm{LF}^{*}$ is around 0.3 . If soils contain gypsum or calcium carbonate, these waters can be used more successfully. EC should not be less than 1 to $2 \mathrm{dS} / \mathrm{m}$. Less permeability problem develops.

- Medium sodicity waters (S3), (SAR/SCAR 20-30): can be used only for crops which are tolerant to sodium on soils provided with good drainage such that $\mathrm{LF}^{*}$ is always greater than 0.3 . If soils contain gypsum or calcium/carbonate and if rainfall is appreciable and effective, these waters can be carefully used. EC should not be less than 2 to $3 \mathrm{dS} / \mathrm{m}$ less permeability problem develops.

- High sodicity waters (S4), (SAR/SCAR 30-40): These waters are directly unsuitable for irrigation without drastic treatment.

- Very high sodicity water (S5), (>40): These waters are unsuitable for irrigation absolutely.

\section{(III) Alkalinity}

The hazards of alkalinity can be estimated by the following criteria:

\section{- $\quad$ Residual Sodium Carbonate (RSC) :}

Bicarbonate ions $\left(\mathrm{HCO}_{3}{ }^{-}\right)$often appear in water with low saline concentration and usually decrease with any increases in water salinity (EC). Increase the proportion of bicarbonate ions $\left(\mathrm{HCO}_{3}{ }^{-}\right)$for calcium ions $\left(\mathrm{Ca}^{2+}\right)$ is one of the undesirable qualities, because after the evaporation of irrigation water, the bicarbonate ions in the water tend to precipitate calcium ions.

The effects of bicarbonate $\left(\mathrm{HCO}_{3}^{-}\right)$along with carbonates $\left(\mathrm{CO}_{3}{ }^{\circ}\right)$ are evaluated by the following equation given RSC (Eaton, 1950):

$$
\begin{aligned}
& \mathrm{RSC}=\left(\mathrm{CO}_{3}{ }^{-}+\mathrm{HCO}_{3}^{-}\right)-\left(\mathrm{Ca}^{2+}+\mathrm{Mg}^{2+}\right) \text {, all ions } \\
& \text { expressed as meq. } l^{-1 .}
\end{aligned}
$$

According to Wilcox, et al. (1954), irrigation water can be classified to three categories according to their content of RSC as shown in Table (8).

\section{- Residual Sodium Bicarbonate (RSBC):}

Because the carbonate $\left(\mathrm{CO}_{3}{ }^{*}\right)$ ions often do not exist in a significant concentration and bicarbonate ions $\left(\mathrm{HCO}_{3}{ }^{-}\right)$did not deposition of magnesium ions $\left(\mathrm{Mg}^{2+}\right)$, Gupta and Gupta (1987) and Todd (1980) suggested the possibility of estimating the alkalinity hazards by using
Residual Sodium Bicarbonate (RSBC) using the following equation:

$\mathrm{RSBC}=\mathrm{HCO}_{3}^{-}-\mathrm{Ca}^{2+}$, all ions expressed as meq.l-1.

Table 8. Irrigation water classes as RSC values

RSC ${\text { (meq. }{ }^{-1} \text { ) Water Quality }}^{-1}$

$<1.25 \quad$ Water probably safe for irrigation.

$2.5-1.25 \quad$ Water marginally suitable for irrigation and

$>2.5 \quad$ Water unsuitable for irrigation purposes.

On the basis of (RSBC) values, it can divide alkalinity risk of irrigation water into six categories:

- Non-alkaline water (- value)

- Normal water $\quad\left(0\right.$ meq..$\left.^{-1}\right)$

- Low alkalinity water $\quad\left(2.5\right.$ meq. $\left.1^{-1}\right)$

- Medium alkalinity water (2.5-5.0 meq. $\left.\mathrm{l}^{-1}\right)$

- High alkalinity water $\quad\left(5.0-10.0\right.$ meq..$\left.^{-1}\right)$

- Very high alkalinity water (> 10.0 meq. $\mathrm{l}^{-1}$ )

(IV) Permeability:

Because of $\mathrm{Na}^{+}$can cause sharp problems in permeability of water through the soil. In the same connection, soil permeability is not affected only by high concentrations of $\mathrm{Na}^{+}$, but also influenced by the presence of ions of $\mathrm{CO}_{3}{ }^{=}$and $\mathrm{HCO}_{3}{ }^{-}$in irrigation water, which precipitates part of them in the form of $\mathrm{CaCO}_{3}$ and $\mathrm{MgCO}_{3}$, which leads to decreasing in $\mathrm{Ca}^{2+}$ concentration. Therefore, negative effects could be arising on soil permeability.

It can assess the impact of the presence of sodium, calcium, and magnesium cations and anions of bicarbonate on the permeability by the term known as (Permeability Index, PI \%) suggested by Doneen (1964) as follow:

Whereas, ions are expressed as meq. $l^{-1}$.

If the value of Permeability Index exceeds $65 \%$, the irrigation water for irrigation considered valid.

Infiltration rate as affected by ECW and SAR

"Infiltration" refers to the entry of water into the soil; the amount of which water enters in unit of time is expressed as the infiltration rate. Ayers and Westcot (1976) submitted the expression of "Permeability" to refer to the percolation of infiltrated water through the soil.

Infiltration problem occurs if the irrigation water does not enter the soil rapidly enough during a normal irrigation cycle, due to the poor of some physical properties such as texture of soil and clay type, to replenish the soil with water needed by the crop before the next irrigation. An infiltration rate as low as $3 \mathrm{~mm} /$ hour is considered low while a rate above 12 $\mathrm{mm} /$ hour is relatively high.

On the other hand, infiltration problem may be occurring due to the quality of the used irrigation water, they caused unfavorable changes in soil chemistry. These unfavorable changes relate directly to rise in salinity (ECw) and sodium adsorption ratio (SAR) of the applied irrigation water, whereas:

* LF : means the leaching fraction, which calculate by using (LF $=E C_{\text {IW }} / \mathrm{EC}_{\mathrm{DW}}$, in $\left.\mathrm{dS} / \mathrm{m}\right)$ ). , defined as the ratio of the quantity of water draining past the root zone to that infiltrated into the soil's surface. 
Table 9. Affects of infiltration rate of water into the soil by EC \& SAR of irrigation water together. Degree of hazards on Use

\begin{tabular}{lccc}
\hline & \multicolumn{3}{c}{ Degree of hazards on Use } \\
\cline { 2 - 4 } & None & \multicolumn{2}{c}{ Slight to Moderate Severe } \\
\hline \multicolumn{3}{c}{ SAR and } & EC(dS/m) together of irrigation water \\
\hline (SAR) & \multicolumn{3}{c}{ EC $(\mathbf{d S} / \mathbf{m})$} \\
\hline $0-3$ & $>0.7$ & $0.7-0.2$ & $<0.2$ \\
$3-6$ & $>1.2$ & $1.2-0.3$ & $<0.3$ \\
$6-12$ & $>1.9$ & $1.9-0.5$ & $<0.5$ \\
$12-20$ & $>2.9$ & $2.9-1.3$ & $<1.3$ \\
$20-40$ & $>5.0$ & $5.0-2.9$ & $<2.9$ \\
\hline
\end{tabular}

*SAR (sodium adsorption ratio) is sometimes reported by $\left(\operatorname{adj} . \mathbf{R}_{\mathrm{Na}}\right)$.

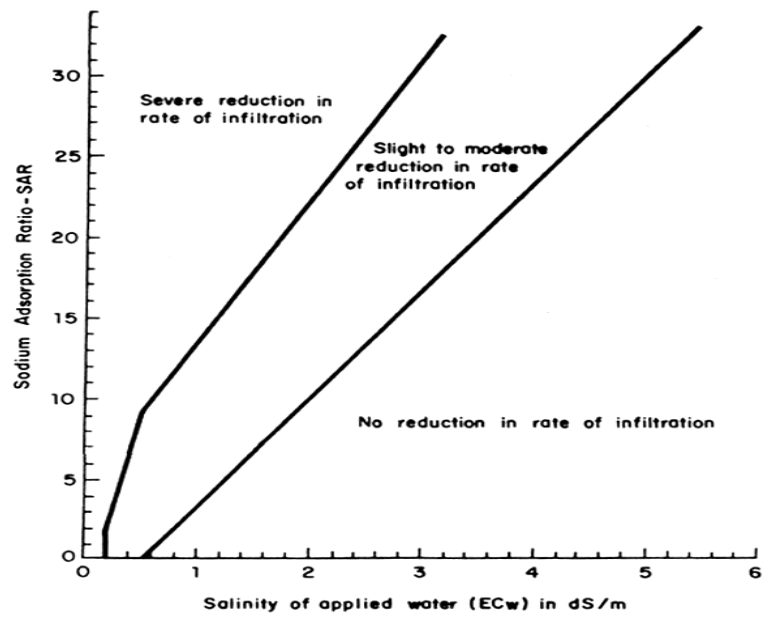

Fig. 2. Infiltration Rate of soil as affected by (ECw) and (SAR) of irrigation water.

- Low salinity water (less than $0.5 \mathrm{dS} / \mathrm{m}$ and especially below $0.2 \mathrm{dS} / \mathrm{m}$ ) is corrosive and tends to leach surface soils free of soluble minerals and salts, especially calcium, reducing their strong stabilizing influence on soil aggregates and soil structure.

Without salts and without calcium, the soil disperses and the dispersed finer soil particles fill many of the smaller pore spaces, sealing the surface and greatly reducing the rate at which water infiltrates the soil surface (infiltration rate). Thus crop emergence problems often result, in addition to a reduction in the Very low salinity water (less than $\mathrm{ECw}=0.2 \mathrm{dS} / \mathrm{m}$ ) almost invariably results in water infiltration problems, regardless of the relative sodium ratio (or SAR). Rainfall is very low salinity water and irrigated areas frequently experience exceptionally low rates of infiltration of rainfall resulting in excessive run off.

- Excessive sodium in irrigation water also promotes soil dispersion and structural breakdown but only if sodium exceeds calcium by more than a ratio of about 3:1. Such a relatively high sodium content (>3:1) often results in a severe water infiltration problem due to soil dispersion and plugging and sealing of the surface pores, in much the same way as does the very low salinity water. This is due to lack of sufficient calcium to counter the dispersing effects of the sodium. Excessive sodium may also make it extremely difficult to supply enough water to meet the crop water demand. Other related problems such as soil crusting, poor seedling emergence, lack of aeration, plant and root diseases and weed \& mosquito control problems caused by the low rate of infiltration may further complicate crop management.

The infiltration rate generally decreases with either decreasing $(\mathrm{ECw})$ or increasing (SAR). While (infiltration rate) increases with increasing (ECw). Therefore, the two factors, salinity and SAR, must be considered together for a proper evaluation of the ultimate effect on water infiltration rate.

Rhoades (1977) and Oster and Schroer (1979) adapted Table (9) gives numerical evaluations of ECW and SAR together on infiltration rate. It can be used with the graphic of Figure (2) to expect general trend of combined effect of both (ECw) and (SAR) of irrigation water on infiltration rate of water into surface soil.

\section{(V) Specific Ion Toxicity Hazards}

\section{- Magnesium Ions}

It believed that the magnesium content and its relationship with the total divalent cations is one of the important measurements in judging of the quality of water for irrigation. Because of higher magnesium content relative to the total divalent cations, high proportion of magnesium may be adsorbed on soil particles and negatively affects on the soil physical properties by causing "magnesia's alkaline" which lead to the occurrence of bad effects on soil properties similar to hazards arising from excess sodium adsorbed ions .This harmful effects of magnesium ions on the soil appear when the value of $(\mathrm{Ca}$ : $\mathrm{Mg}$ ratio) decline below (Ca: $\mathrm{Mg}$ ratio < 50).

$\mathrm{Mg}$ adsorption Ratio =

whereas , ions are expressed as me. $1^{-1}$.

Chloride Ions

The concentration of chloride ions in irrigation water increased with the increasing in the $\mathrm{ECw}$ value and increasing of sodium ions concentration. Therefore, these ions are the most dominant ions in very high saline water. Chloride ions not affected on soil physical properties, because of it is not adsorbed on soil particles. Therefore it has generally not been included in modern classification system. However in some regional water, chloride used as a as classification factor, because it's effect on some crops and plants grown in this regions. Quality of water for irrigation as for its $\mathrm{Cl}^{-1}$ content, classified to five classes as shown in Table (10). Also, FAO (1994) presented other classification about the hazards degree of chloride on irrigation water depending upon the methods of irrigation used as shown in Table (11).

Table 10. Irrigation water classes as $\mathrm{Cl}^{-}$conc.

\begin{tabular}{lc}
\hline Water Quality & Cl $^{-}$Conc. $\left(\right.$meq..$\left.^{-1}\right)$ \\
\hline Excellent Water. & $<4$ \\
Good water. & $4-7$ \\
Slightly usable. & $7-12$ \\
Not suitable. & $12-20$ \\
Not suitable. & $>20$ \\
\hline
\end{tabular}

Table 11. Irrigation water classes as $\mathrm{Cl}^{-}$conc. $\left(\right.$ meq..$\left.^{-1}\right)$ based on irrigation methods,

\begin{tabular}{lccc}
\hline \multirow{2}{*}{$\begin{array}{l}\text { Irrigation } \\
\text { Methods }\end{array}$} & \multicolumn{3}{c}{ Degree of Restriction on Use } \\
\cline { 2 - 3 } & No & Slight to Moderate & Severe \\
\cline { 2 - 3 } & \multicolumn{2}{c}{$\mathbf{C l}^{\mathbf{*}}$ in irrigation water $\left(\mathbf{m e}^{\mathbf{1}} \mathbf{I}^{\mathbf{1}}\right)$} \\
\hline Surface & $<4$ & $4-10$ & $>10$ \\
Sprinkler & $<3$ & $>3$ & \\
\hline
\end{tabular}




\section{Notes}

For surface irrigation, most tree crops and woody plants are sensitive to sodium and chloride; use the values shown. Most annual crops are not sensitive; use the common crops tolerate for salinity. Use the values shown; for chloride tolerance of selected fruit crops.

With overhead sprinkler irrigation and low humidity with $<30 \%$, sodium and chloride may be absorbed through the leaves of sensitive crops.

\section{Sulphate Ions}

Sulphate salts are less harmful when compared to chlorides. This is because when the both ions occur in this concentration, only half of the sulphate ions contribute to salinity due to the fact that approximately half of the sulphates get precipitated as $\mathrm{CaSO}_{4}$ while the other half remains in soluble form as $\mathrm{NaSO}_{4}$ or $\mathrm{MgSO}_{4}$ in the soil. In this respect, Eaton (1950) proposed three water classes as sulphate concentration, meq. $1^{-1}$ :

$<4$ (meq. $\left.\mathrm{l}^{-1}\right)$ : Excellent water

4-12 (meq. $\left.1^{-1}\right)$ : Good to injurious

$>12$ (meq. $1^{-1}$ ): Injurious to unsatisfactory

On the other hand, it can recommended with the suitability of water for irrigate according to the degree of soil permeability on the basis of Potential salinity (PSi.w , me..$^{-1}$ ) , which calculated from the following formula:

$\left(\mathrm{PS}_{\mathrm{i} . \mathrm{w}}=\mathrm{Cl}^{-}+1 / 2 \mathrm{SO}_{4}{ }^{=}\right)$

Whereas, ions are expressed in meq. $1^{-1}$

From these classifications Table (12), it can determine the suitability for use in irrigation according to the effect of potential salinity on soil permeability.

Table 12 . Soil permeability classes as Potential salinity (PS Potential salinity i.w , meq..$^{-1}$ ) of irrigation water.

\begin{tabular}{lc}
$\begin{array}{l}\left.\text { (meq } .^{-\mathbf{l}^{\mathbf{1}}}\right) \\
3-15\end{array}$ & $\begin{array}{c}\text { Remarks } \\
\text { Can recommended for medium } \\
\text { permeability soils. } \\
\text { Recommended for soils of low } \\
\text { permeability. }\end{array}$ \\
\hline
\end{tabular}

\section{Boron Content}

It is evident that boron is essential for the normal growth of the plant, but the amount required is very small. The occurrence of boron in toxic concentration in certain irrigation water makes it necessary to consider this element in assessing the water quality. The permissible limits of boron in irrigation water are shown in Table (13):

Table 13 . Irrigation water classes and suitability for crops according to Boron content (mg.l $\left.{ }^{-1}\right)$.

\begin{tabular}{|c|c|c|c|c|}
\hline \multirow{2}{*}{$\begin{array}{l}\text { Remarks } \\
\text { For safely use. }\end{array}$} & \multicolumn{3}{|c|}{$\begin{array}{c}\text { Crops } \\
\text { Tolerant Semi-tolerant Sensitive } \\
\text { Boron content }\left(\mathrm{mg} . \mathrm{l}^{-1}\right)\end{array}$} & \multirow{2}{*}{\begin{tabular}{|c}
$\begin{array}{c}\text { Boron } \\
\text { Class }\end{array}$ \\
Very Low \\
\end{tabular}} \\
\hline & $<1.00$ & $<0.67$ & $<0.33$ & \\
\hline Can be managed. & $\begin{array}{c}1.00- \\
2.00\end{array}$ & $\begin{array}{c}0.67- \\
1.33\end{array}$ & $\begin{array}{c}0.33- \\
0.67\end{array}$ & Low \\
\hline Unsuitable. & $\begin{array}{c}2.00- \\
3.00\end{array}$ & $\begin{array}{c}1.33- \\
2.00\end{array}$ & $\begin{array}{c}0.67- \\
1.00\end{array}$ & Medium \\
\hline Unsuitable. & $\begin{array}{c}3.00- \\
3.75 \\
\end{array}$ & $\begin{array}{c}2.00- \\
2.50 \\
\end{array}$ & $\begin{array}{c}1.00- \\
1.25 \\
\end{array}$ & High \\
\hline Unsuitable. & $>3.75$ & 2.50 & 1.25 & $\begin{array}{l}\text { Very } \\
\text { High }\end{array}$ \\
\hline
\end{tabular}

\section{- Nitrate- Nitrogen Content}

Very frequently of the ground water are contain high amounts of $\left(\mathrm{NO}_{3}-\mathrm{N}\right)$. When such type of irrigation water is applied on soils continuously, a lot of characteristics of growing crops may be affected, but it did not affected negatively on soil properties.

The boundaries of nitrate concentration (me. $1^{-1}$ ) in water and its problem degree arise of use it in irrigation is:

\begin{tabular}{lc}
\hline Problem degree & $\mathbf{N O}_{\mathbf{3}}-\mathbf{N}\left(\mathbf{m g . \mathbf { l } ^ { - 1 }}\right)$ \\
\hline No Problem & $<5$ \\
Slight to moderate Problem & $5-30$ \\
severe Problem & $>30$ \\
\hline
\end{tabular}

As FAO (1994)

\section{Lithium content}

Lithium is consider a mobile trace element in soil and may be found in most of saline ground water and irrigated soils. Most crops can tolerate "Li" by up to 5 $\mathrm{mg} / \mathrm{l}$. However Li concentrations < $0.075 \mathrm{mg} / \mathrm{l}$. induces toxic effect to citrus. It is reported that some saline soils ,at some regions, may contain varying degrees of lithium content may be arrive to $2.5 \mathrm{ppm}$,but fortunately, the germination of most crops in these regions not affected by the concentration of lithium.

\section{Resumr}

A lot of criteria all or some of them could be use to determine the water hazards and suitability to irrigate different of crops. Criteria, which summarized in this scientific essay, were:

\section{- Salinity hazard:}

Salinity is classified into four classes of salinity hazard, whatever of total salinity $\mathrm{EC}\left(\mathrm{dSm}^{-1}\right)$ or total dissolved salts (TDS, ppm).

Also, salt index (SI) from formula of :

$$
(\mathrm{SI})=\left(\text { Total } \mathrm{Na}^{+}-24.5\right)-\left(\text { total } \mathrm{Ca}^{2+} \text { in } \mathrm{CaCO}_{3}\right)
$$

$\mathrm{x}$ 4.85. can be use to determine salinity hazards.

\section{- Sodicity hazard:}

- Sodium hazard could be determined with six methods:

- $\quad \mathrm{SR}=\left(\mathrm{Na}^{+}\right) /\left(\mathrm{Ca}^{2+}+\mathrm{Mg}^{2+}\right)$, should be not exceed (1) for good water.

- $\quad \mathrm{SSP}=$ (soluble Na conc./ Total Cation conc.) $\mathrm{x}$ 100, whereas, SSP > 66 was bad for soil and plant.

$$
\mathbf{S A R}=\frac{\left(\mathrm{Na}^{+}\right)}{\sqrt{\frac{\left(\mathrm{Ca}^{2+}+\mathrm{Mg}^{2+}\right)}{2}}}
$$

- "adj SAR" can be calculated from pHc which values verses to $\mathrm{Ca}+\mathrm{Mg}+\mathrm{Na}, \mathrm{Ca}+\mathrm{Mg}$ and $\mathrm{CO}_{3}+\mathrm{HCO}_{3}$, therefore adj SAR $=\mathrm{SAR}(1+(8.4-\mathrm{pHc}))$

- $\quad \operatorname{adj} \mathrm{R}_{\mathrm{Na}}$ " which depend upon a modified calcium value due to estimated partial pressure of $\mathrm{CO}_{2}$, that take in mined $\mathrm{HCO}_{3} / \mathrm{Ca}$ and $\mathrm{ECw}$ to calculate $\mathrm{Ca}_{\mathrm{x}}$.

- Sodium to calcium activity ratio, i.e. $(\mathrm{SCAR})=(\mathrm{Na} / \sqrt{\mathrm{Ca}})$

\section{- Alkalinity hazard:}

It can be estimated as:

- Residual sodium carbonate

$\mathrm{RSC}=\left(\mathrm{CO}_{3}+\mathrm{HCO}_{3}\right)-\left(\mathrm{Ca}^{2+}+\mathrm{Mg}^{2+}\right)$

- Residual sodium bicarbonate

$\mathrm{RSBC}=\left(\mathrm{HCO}_{3}-\mathrm{Ca}^{2+}\right)$.

- Permeability (IP\%):

\section{Whereas}

If "PI\%" exceeds $65 \%$, the irrigation considered valid. 
Also, infiltration rate depends on both of ECw \& SAR was summarized

\section{- Ion toxicity hazard :}

Remarks on the suitable borders of $\mathrm{Mg}, \mathrm{Cl}, \mathrm{SO}_{4}$, $\mathrm{B}, \mathrm{NO} 3-\mathrm{N}$ and $\mathrm{Li}$, to avoid incidence a toxic effects of them were summarized.

\section{REFERENCES}

Ayers R.S. and Westcot D.W. (1976). Water Quality for Agriculture. FAO:29.

Doneen LD (1964). Notes on water quality in Agriculture. Published as a Water Science and Engineering Paper 4001, Department of Water Sciences and Engineering, University of California

Eaton, F.M. (1950). Significance of carbonates in irrigation waters. Soil Sci. 69, 123-133

FAO (1994), Water Quality for Agriculture. Irrigation and Drainage Paper.. 29 Rev.2, FAO, Rome

Gupta, I.C, and Abichandani.C.T. (1970). Use of saline water predominant in divalent cations in semiarid- zones of western rajasthan.Ind.J. Agric.Sci. 40: $711-715)$

Gupta, S.K. and I.C. Gupta, (1987). Management of Saline Soils and Water. Oxford and IBH Publication Coy, New Delhi, India, pp: 399.

Oster J.D. and Rhoades J.D. (1977). Various indices for evaluating the effective salinity and sodicity of irrigation waters. In: Proc. International Salinity Conference, Lubbock, Texas, 16- 20 August 1976. pp. 1-14.

Oster J.D. and Schroer F.W. (1979). Infiltration as influenced by irrigation water quality. Soil Sci. Soc. Amer. J. 43:444-447.
Rhoades J.D. (1977). Potential for using saline agricultural drainage waters for irrigation. Proc. Water Management for Irrigation and Drainage. ASCE, Reno, Nevada. 20-22 July 1977. pp. 85116.

Rhoades J.D. (1982). Reclamation and management of salt-affected soils after drainage. Proc. First Annual Western Provincial Conference on Rationalization of Water and Soil Research and Management, Alberta, Canada. pp. 123-197.

Richards L.A. (1954). Diagnosis and Improvement of saline and alkali soils. USDA Agricultural Handbook No. 60, US Department of Agriculture, Washington DC.

Singh N.T. (2005). "Irrigation and Soil Salinity in the Indian Subcontinent: Past and Present" (2005) Lehigh University Press,

Suarez D.L. (1981). Relation between pHc and Sodium Adsorption Ratio (SAR) and an alternate method of estimating SAR of soil or drainage waters. Soil Sci. Soc. Amer. J. 45:469-475.

Todd, D.K., (1980). Groundwater Hydrology. 2nd Edition, Wiley \& Sons, New York, pp 535.)

UCCC (University of California Committee of Consultants) (1974). FAO, 1994. 29(Rev.2)

USSL (U.S. Salinity Lab.) staff (1954). Diagnosis and Improvement Saline and Alkaline Soil. Agric. Handbook 60.

Wilocx, L.V. (1948). The Quality of Water for Irrigation Use. U. S. Dep. Sgric. Tech. Bull., 962:1-40.

Wilcox L.V.(1966) . Tables of Calculating the pHc Values of Water. US Salinity Laboratory Mimeo Report.

Wilcox L.V., Blair G.Y. and Bower C.A. (1954). Effect of Bicarbonate on Suitability of water for Irrigation. Soil Science 77:259-266.

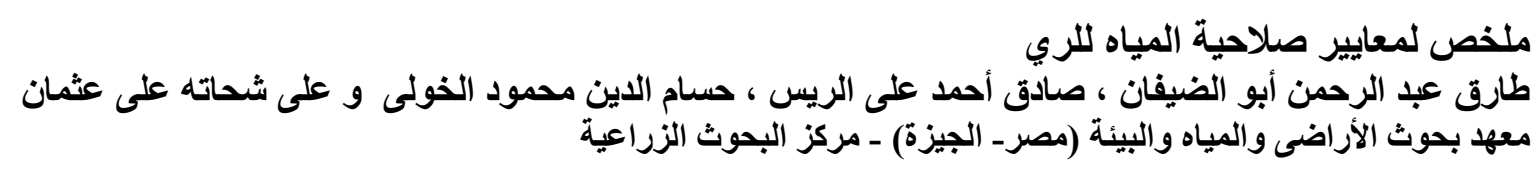

يهدف هذا المقال العلمي إلى تلخيص لأهم القياسات المتعلقة بتحديد مدى جودة المياه للإستخدام فى رى مخ مختلف

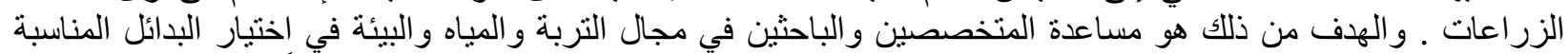

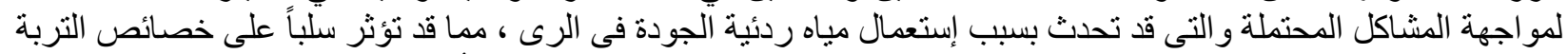

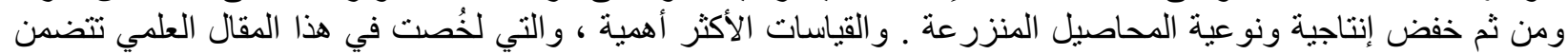

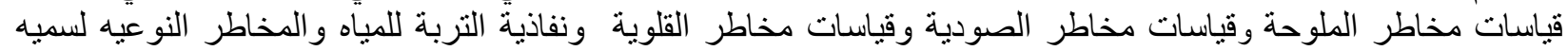
بعض الأيونات. 